\title{
A Multiplex PCR Assay to Characterize Potato virus $Y$ Isolates and Identify Strain Mixtures
}

\author{
James H. Lorenzen, PSES Department, University of Idaho, Moscow 83844; Lisa M. Piche and Neil C. Gudmestad, \\ Department of Plant Pathology, North Dakota State University, Fargo 58105; and Teresa Meacham and Pat Shiel, \\ PSES Department, University of Idaho, Moscow 83844
}

\begin{abstract}
Lorenzen, J. H., Piche, L. M., Gudmestad, N. C., Meacham, T., and Shiel, P. 2006. A multiplex PCR assay to characterize Potato virus $Y$ isolates and identify strain mixtures. Plant Dis. 90:935940.

Potato virus $Y$ (PVY) has become a serious problem for the seed potato industry, with increased incidence and rejection of seed lots submitted for certification. New PVY strains and strain variants have emerged in recent decades in Europe and North America, including the PVY ${ }^{\mathrm{N}}$ strain that causes veinal necrosis in tobacco, and strain variants that represent one or three recombination events between the common strain $\left(\mathrm{PVY}^{\mathrm{O}}\right)$ and $\mathrm{PVY}^{\mathrm{N}}$. Several reverse transcriptionpolymerase chain reaction (RT-PCR) assays have been described that characterize PVY isolates as to strain type, but they are limited in their ability to detect some combinations of mixed strain infections. We report here the development of a single multiplex RT-PCR assay that can assign PVY strain type and detect mixed infections with respect to the major strain types. Validation of this assay was achieved using 119 archived PVY isolates, which had been previously characterized by serology and bioassay and/or previously published RT-PCR assays. Results for singlestrain isolates were comparable to previous results in most cases. Interestingly, 16 mixed infections were distinguished that had previously gone undetected. The new multiplex RT-PCR assay will be useful for researchers and seed production specialists interested in determining PVY infection type using a single assay.
\end{abstract}

Potato virus $Y$ (PVY) is the type member of the Potyvirus family and infects several important crops of the Solanaceae family, including potato, tomato, pepper, and tobacco $(4,15)$. There are several widely recognized strains of PVY, including the common strain $\left(\mathrm{PVY}^{\mathrm{O}}\right)$, the tobacco necrosis strain $\left(\mathrm{PVY}^{\mathrm{N}}\right)$, and $\mathrm{PVY}^{\mathrm{C}}$ causing stipple streak (4). The common strain of PVY that produces foliar mosaic symptoms has been the predominant strain in PVY-infected seed potatoes in North America (5). In recent years, other PVY strain variants have been reported from within North America $(10,13)$. The PVY ${ }^{\mathrm{N}}$ strain causes veinal necrosis on tobacco leaves (4). The origins of $\mathrm{PVY}^{\mathrm{N}}$ are diffi-

Corresponding author: J. H. Lorenzen

E-mail: jiml@uidaho.edu

Current address for Pat Shiel: USDA-APHIS-PPQ, Center for Plant Health Science and Technology (CPHST), Raleigh, NC 27606

Accession numbers: AJ584851, AJ585195, AJ585196, AJ585197, AJ585198, AJ585342, AY166866, AY166867, AY745491, AY745492, AY884982, AY884983, AY884984, AY884985, DQ008213, DQ157178, DQ157179, M95491, U09509, X12456, X97895.

Accepted for publication 1 March 2006.

DOI: 10.1094/PD-90-0935

(C) 2006 The American Phytopathological Society cult to pinpoint, although early reports suggest it was first detected in South America more than 70 years ago $(16,17)$. More recently, variants and recombinants of PVY have been detected. Tuber necrosis strains of PVY (PVY $\left.{ }^{\mathrm{NTN}}\right)$ were first detected in Europe (Eu-PVYNTN) and are characterized by a $\mathrm{PVY}^{\mathrm{N}}$ serotype and by having three recombination junctions $(6,8)$. Tuber necrosis strains in North America are also characterized by a $\mathrm{PVY}^{\mathrm{N}}$ serotype but have either no or a single recombination junction $(10,13)$. Other PVY recombinants such as $\mathrm{PVY}^{\mathrm{N}: \mathrm{O}}$ also have a single recombinant junction but are unique in that they have a $\mathrm{PVY}^{\mathrm{O}}$ serotype $(2,11)$. Some of the latter types of PVY ${ }^{\mathrm{N}: \mathrm{O}}$ can cause an atypical tuber necrosis (13). We have recently completed the confirmation of these recombination events by whole-genome sequencing of the $\mathrm{PVY}^{\mathrm{N}}$ and $\mathrm{PVY} \mathrm{YTN}^{\mathrm{NTN}}$ strains in North America (9). Based on the sequence analysis of the PVY genomes and on symptomatology (13), it is evident that $\mathrm{PVY}^{\mathrm{N}}$ and $\mathrm{PVY}^{\mathrm{NTN}}$ isolates from Europe are different than those recovered from North America.

Our research programs have worked with three widely accepted reverse transcription-polymerase chain reaction (RTPCR) assays used to identify PVY strain types (3,11-13). A multiplex RT-PCR assay developed by Nie and Singh (11) queries the P1 cistron and differentiates PVY into two main groups: those that produce leaf necrosis on tobacco indicator plants (European $\mathrm{PVY}^{\mathrm{N}}$, European $\mathrm{PVY}^{\mathrm{NTN}}$, $\mathrm{PVY}^{\mathrm{N}: \mathrm{O}}$ (or PVY ${ }^{\mathrm{N}}-\mathrm{Wi}$ ), North American $\mathrm{PVY}^{\mathrm{N}}$ and North American PVY ${ }^{\mathrm{NTN}}$ ) and those that do not produce leaf necrosis on tobacco $\left(\mathrm{PVY}^{\mathrm{O}}\right)(11,12)$. For simplicity, North American PVY tobacco necrotic isolates will be designated as NA-PVYN and NA-PVYNTN, while European PVY ${ }^{\mathrm{N}}$ or European PVY $Y^{\text {NTN }}$ will be referred to as $\mathrm{PVY}^{\mathrm{N}}$ and PVY ${ }^{\mathrm{NTN}}$, respectively. The Nie and Singh (11) assay can detect mixtures of $\mathrm{PVY}^{\mathrm{O}}$ plus $\mathrm{PVY}^{\mathrm{N}}$ (including PVY $\mathrm{PVN}^{\mathrm{NTN}}$ and $P V Y^{\mathrm{N}: \mathrm{O}}$ ). A second multiplex assay, developed by the same research group (12), was used in conjunction with the P1 assay to identify isolates capable of producing necrotic lesions on tobacco leaves, and it also identifies recombinants of the $\mathrm{PVY}^{\mathrm{NTN}}$ and PVY ${ }^{\mathrm{N}: \mathrm{O}}$ types based on amplification of three amplicons or one amplicon, around the respective recombination junctions. A third assay is based on HincII restriction digests of P1 amplicons and can differentiate $\mathrm{PVY}^{\mathrm{O}}$ from the necrotic strains of $\mathrm{PVY}^{\mathrm{N}}, \mathrm{PVY}^{\mathrm{NTN}}, \mathrm{PVY}^{\mathrm{N}: \mathrm{O}}$, $\mathrm{PVY}^{\mathrm{NA}-\mathrm{N}}$, and PVY $\mathrm{YA-NTN}^{\mathrm{N}}$ (3). This assay will also detect strain mixtures of $\mathrm{PVY}^{\mathrm{O}}$ and $\mathrm{PVY}^{\mathrm{N}}, \mathrm{PVY}^{\mathrm{NTN}}$, NA-PVY ${ }^{\mathrm{N}}$, or NA$\mathrm{PVY}^{\mathrm{NTN}}$. The above assays are limited in providing unambiguous identification of strain mixtures from within the necrotic groups of $\mathrm{PVY}^{\mathrm{N}}, \mathrm{PVY}^{\mathrm{NTN}}, \mathrm{PVY}^{\mathrm{N}: \mathrm{O}}$, NA$\mathrm{PVY}^{\mathrm{N}}$, or NA-PVYNTN . Two other assays have been described to detect mixtures of $\mathrm{PVY}^{\mathrm{O}}$ and $\mathrm{PVY}^{\mathrm{N}}$ serotypes using specific fluor-labeled primers to the coat protein region (18), or separate PCR assays for $\mathrm{PVY}^{\mathrm{O}}, \mathrm{PVY}^{\mathrm{N}}$, or $\mathrm{PVY}^{\mathrm{C}}(1)$.

A recent report indicated the presence of new variants of some of the above strains (13). These "strain variants" included individual isolates that reacted with monoclonal antibodies specific for both $\mathrm{PVY}^{\mathrm{N}}$ and $\mathrm{PVY}^{\mathrm{O}}$. Although the authors used available RT-PCR tests to characterize strain types and identify strain mixtures $(11,12)$, reaction with both antibody types indicated either a changed epitope profile that would react to both specific antibodies or a mixture of strains that was not detectable using the current nucleic acid-based assays. During the course of characterizing these "novel" isolates before sequencing to try to predict the amino acid change(s) responsible for the epitope change, it became apparent that two of these isolates were mixed infections of $\mathrm{PVY}^{\mathrm{NTN}}$ and 
PVY ${ }^{\mathrm{N}: \mathrm{O}}$ (unpublished data). This paper describes the development of a new multiplex PCR assay capable of differentiating major PVY strain types and mixed infections thereof in a single assay.

\section{MATERIALS AND METHODS}

Strain-specific primers were designed using the program FastPCR (Kalendar 2004, available online from Institute of Biotechnology, University of Helsinki) with the following parameters: Tm range 50 to $70^{\circ} \mathrm{C}$ (primers with $\mathrm{Tm}$ of 58 to $60^{\circ} \mathrm{C}$ were chosen for this multiplex assay), CG Range 35 to $70 \%$, primer length 18 to 30 , quality score minimum 50 , and screening data set. Representative isolates used for primer design for each respective class were: $\mathrm{PVY}^{\mathrm{N}}$-Mont (AY884983), $\mathrm{PVY}^{\mathrm{O}}$ 139 (U09509), and NA-PVY ${ }^{\mathrm{N}}$-RRA-1 (AY884984). For each strain type, a screening data set consisting of several representative sequences of each of the other strain types was used to design primers that would not amplify nontarget strain types. This data set included all available full-length PVY genomes, excluding the strain variant class for which primers were being sought, and strain variants that were essentially the same strain type at the point of primer design (Fig. 1). Potential primers were further screened by FastPCR using its "in silico PCR" feature against a database of all available full-length PVY genome sequences (GenBank + in-house) to select primers unlikely to amplify nontarget strains or nonspecific products. The primers S5585 and A6032 (12) were modified to increase $\mathrm{Tm}$ by increasing length and G/C content. Several variant designs of these primers were tested by in silico PCR as described above to select primers that were optimized for specificity, quality score, and compatible Tm. The primers, their genomic location, and expected target amplicons are described in Tables 1 and 2.

Virus extraction at the University of Idaho utilized a crude nucleic acid preparation, as described in Crosslin et al. (3). Reverse transcription was performed using $0.8 \mu \mathrm{l}$ of virus extract in a $15-\mu \mathrm{l}$ reaction volume that contained $50 \mathrm{mM}$ Tris- $\mathrm{HCl}$ (pH 8.3), $75 \mathrm{mM} \mathrm{KCl}, 8 \mathrm{mM} \mathrm{MgCl}_{2}, 1$ $\mathrm{mM}$ (each) dNTP, $0.12 \mu \mathrm{M}$ oligo-dT primer mix, 6 units RNase Out Ribonuclease Inhibitor (Invitrogen, Carlsbad, CA), and 60 units of SSII reverse transcriptase (Invitrogen). The RT program for firststrand cDNA synthesis started at room temperature, ramped to $42^{\circ} \mathrm{C}$ at $2^{\circ} \mathrm{C} / \mathrm{min}$, held at $42^{\circ} \mathrm{C}$ for $45 \mathrm{~min}$, and ramped to $60^{\circ} \mathrm{C}$ at $0.5^{\circ} \mathrm{C} / \mathrm{min}$. PCRs were performed in a $20-\mu 1$ reaction volume that contained $0.8 \mu \mathrm{l}$ cDNA from above, $10 \mathrm{mM}$ Tris- $\mathrm{HCl}$ (pH 8.3), $50 \mathrm{mM} \mathrm{KCl}, 1.8 \mathrm{mM} \mathrm{MgCl}_{2}, 0.2$ $\mathrm{mM}$ (each) dNTP, $0.12 \mu \mathrm{M}$ for all eight primers (Tables 1 to 3), and 1.0 unit Taq DNA polymerase (Promega, Madison, WI). The "touch-down" PCR program consisted of denaturing at $94^{\circ} \mathrm{C}$ for $2 \mathrm{~min}$, 12 cycles of $94^{\circ} \mathrm{C}$ for $10 \mathrm{~s}, 66^{\circ} \mathrm{C}$ for $30 \mathrm{~s}$ (minus $0.5^{\circ} \mathrm{C}$ per cycle), and $60 \mathrm{~s}$ at $72^{\circ} \mathrm{C}$, followed by 20 cycles of $92^{\circ} \mathrm{C}$ for $10 \mathrm{~s}$, $60^{\circ} \mathrm{C}$ for $30 \mathrm{~s}$, and $72^{\circ} \mathrm{C}$ for $60 \mathrm{~s}$, ending with a final extension for $7 \mathrm{~min}$ at $72^{\circ} \mathrm{C}$. At North Dakota State University (NDSU), total nucleic acid was extracted, reverse transcribed into cDNA, and stored at $-80^{\circ} \mathrm{C}$, as previously described (13). One to five microliters of cDNA was used in the same PCR assay described above.

PCR products were separated in a horizontal gel consisting of $0.7 \%$ agarose + $1.2 \%$ Synergel (Diversified Biotech, Boston, MA) or a vertical $15 \%$ native polyacrylamide gel and visualized with a fluorescent imager after staining with GelStar (Cambrex, Rockland, ME) or ethidium bromide.

To validate this assay, we recharacterized virus isolates collected in recent years and stored as either extracted RNA or as cDNA at our respective laboratories (P. Shiel and T. Meacham, unpublished; 3). These isolates represent a mix of samples submitted by other researchers, producers, or industry representatives and are not a random representation of strain types from any geographic region. For historical rea-

\begin{tabular}{|l|l|l|l|l|l|l|l|l|}
0 & 1 & 2 & 3 & 6 & & & \\
\hline
\end{tabular}

\begin{tabular}{|l|l|l||l|l|l|l|l|}
\hline P1 & HC-Pro & P3 & CI & VPG & NIa & NIb & CP \\
\hline \multicolumn{7}{|c|}{$6 \mathrm{~K} 2$} \\
\hline
\end{tabular}
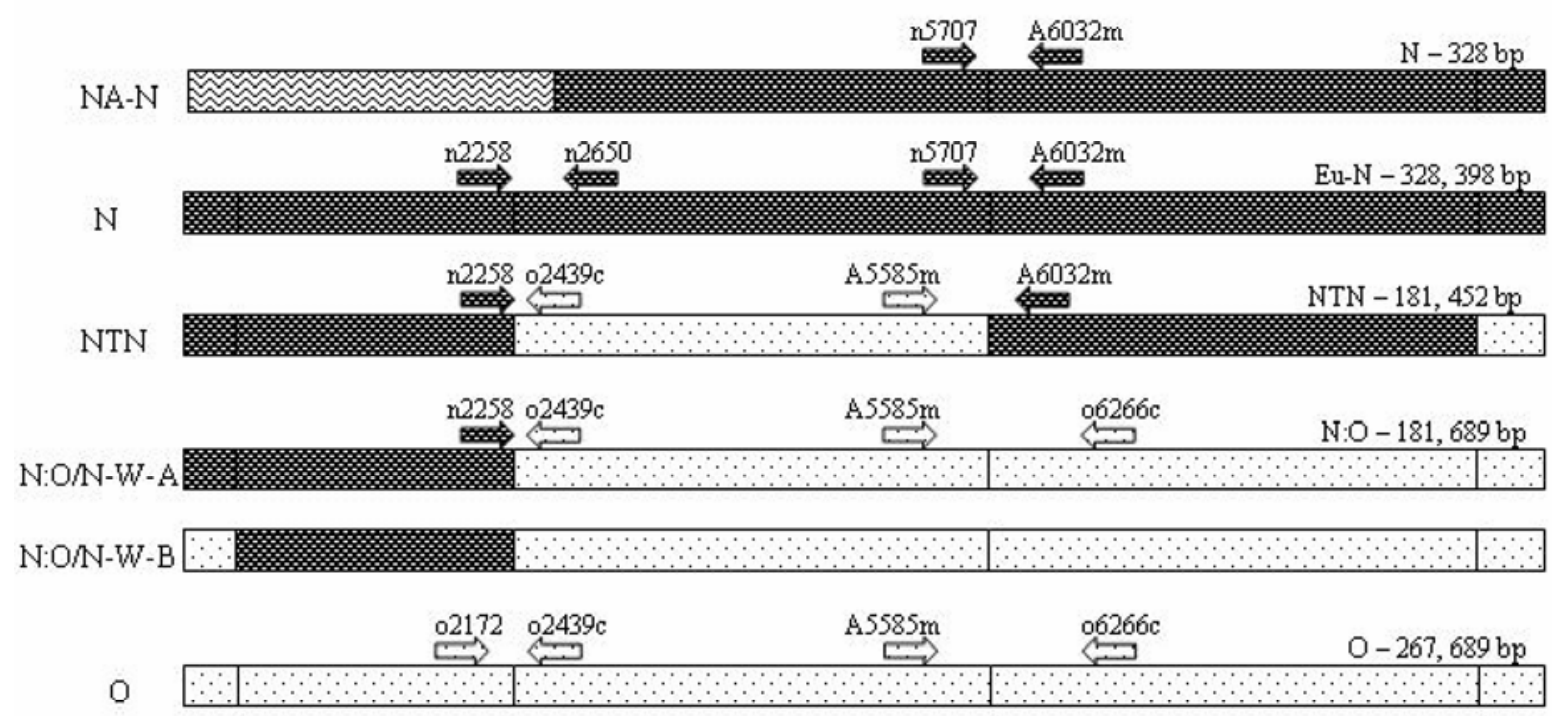

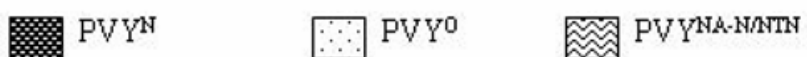

Fig. 1. Primer location with regard to strain types, recombination junctions, and amplified products of Potato virus $Y$ (PVY). The ruler bar indicates position in the genome (in kbp); the underlying boxes indicate the various cistrons of the polyprotein. Primer positions expected to result in amplicons are indicated above the respective strains; expected amplicon sizes are indicated over the $3^{\prime}$ end of each strain bar. Representative full-length sequences for PVY isolates represented by the bars are given as follows: NA-N/NTN - RRA-1 (AY884984), N-Jg (AY166867), SASA-61 (AJ585198), Tu 660 (AY166866); N - Mont (AY884983), N605 (X97895), SCRI-N (AJ585197); NTN - 423-3 (AY884982), Hun-NTN (M95491), NIB-NTN (AJ585342); N:O/N-W-A - SASA-207 (AJ584851), L-56 (AY745492), Mb112 (AY745491), Alt (AY884985), OR-1 (DQ157179), ID-1 (DQ157178); N:O/N-W-B - PN_10A (DQ008213); O SASA-110 (AJ585195), SCRI-O (AJ585196), O-139 (U09509), Fr (X12456). 
sons, this collection of samples archived at the University of Idaho was composed of $\mathrm{PVY}^{\mathrm{N}}$ serotypes. For comparison with previous RT-PCR characterization, the following assays were used. The P1 cleaved amplified polymorphic sequence assay described in Crosslin et al. (3) had been previously used to characterize the 49 isolates collected at the University of Idaho. The series of two multiplex assays

Table 1. Potato virus $Y$ primers used in the multiplex assay and supplementary assays and their genomic locations

\begin{tabular}{llll}
\hline Assay & Primer & Sequence $\mathbf{( 5}^{\prime}$-3' & Position \\
\hline Multi & o $2172^{\mathrm{a}}$ & CAACTATGATGGATTTGGCGACC & 2172 \\
Multi & n2258 & GTCGATCACGAAACGCAGACAT & 2258 \\
Multi & o2439c & CCCAAGTTCAGGGCATGCAT & $2487 \mathrm{r}$ \\
Multi & n2650c & TGATCCACAACTTCACCGCTAACT & $2650 \mathrm{r}$ \\
Multi & n5707 & GTGTCTCACCAGGGCAAGAAC & 5707 \\
Multi & o6266c & CTCCTGTGCTGGTATGTCCT & $6266 \mathrm{r}$ \\
Multi & S5585m & GGATCTCAAGTTGAAGGGGAC & 5584 \\
Multi & A6032m & CTTGCGGACATCACTAAAGCG & $6033 \mathrm{r}$ \\
N:O-B & O102F & CCTTGCAATTCTCTTAAACGGT & 102 \\
N:O-B & N620R & CTGTCAACTTTGGCGTGTGATA & $620 \mathrm{r}$ \\
NA-N/NTN & NA461 & ACACAACTTCCAAATGGCTGCAC & 461 \\
NA-N/NTN & NA1358c & GGTTCAGTCAAGTGCTCTAGGAC & $1358 \mathrm{r}$ \\
\hline
\end{tabular}

${ }^{\text {a }}$ Primer numbers reflect position in a multiple sequence alignment according to position number of N605 (X97895) for primers o2172, n2258, o2439c, n2650c, n5707, N620R, NA461, NA1358c; numbers according to $\mathrm{O} 139$ (U09509) for primers $06266 \mathrm{c}$ and O102F; or numbers given by Nie and Singh (12) for primers S5585m and A6032m.

Table 2. Expected sizes of polymerase chain reaction (PCR) products and target strains for Potato virus $Y$ (PVY) primer combinations in the multiplex assay

\begin{tabular}{llll}
\hline Primer combination & Size & Target strain & Region \\
\hline $\mathrm{n} 2258+\mathrm{o} 2439 \mathrm{c}$ & $181 \mathrm{bp}$ & $\mathrm{NTN}, \mathrm{N}: \mathrm{O}$ & RJ1 $^{\mathrm{a}}$ \\
$\mathrm{o} 2172+\mathrm{o} 2439 \mathrm{c}$ & $267 \mathrm{bp}$ & $\mathrm{O}$ & NoRJ \\
$\mathrm{n} 2258+\mathrm{n} 2650 \mathrm{c}$ & $398 \mathrm{bp}$ & $\mathrm{N}$ & NoRJ \\
$\mathrm{n} 5707+\mathrm{A} 6032 \mathrm{~m}$ & $328 \mathrm{bp}$ & $\mathrm{N}, \mathrm{NA}-\mathrm{N} / \mathrm{NTN}$ & NoRJ \\
$\mathrm{S} 5585 \mathrm{~m} \mathrm{A6032m}$ & $452 \mathrm{bp}$ & $\mathrm{NTN}$ & RJ2 \\
$\mathrm{S} 5585 \mathrm{~m}$ o6266c & $689 \mathrm{bp}$ & $\mathrm{N}: \mathrm{O}, \mathrm{O}$ & NoRJ \\
$2172+\mathrm{n} 2650 \mathrm{c}$ & not exp. & $\ldots$ & $\ldots$ \\
$\mathrm{n} 5707+\mathrm{o} 6266 \mathrm{c}$ & not exp. & $\ldots$ & $\ldots$ \\
\hline
\end{tabular}

${ }^{\mathrm{a}} \mathrm{RJ}=$ recombinant junction, numbered according to Nie and Singh (12).

${ }^{\mathrm{b}}$ not exp. $=$ a possible primer combination that is not expected to produce a product based on known PVY genomes.

described by Nie and Singh $(11,12)$ were used to characterize the 70 isolates collected at NDSU. In addition, the NDSU isolates were characterized by serological and biological assays as described by Piche et al. (13).

\section{RESULTS}

The RT-PCR reactions using known isolates previously characterized by wholegenome sequencing gave products of the expected sizes (Figs. 1 and 2, Tables 2 and 3). $\mathrm{PVY}^{\mathrm{N}: \mathrm{O}}$ isolates gave products of 181 and $689 \mathrm{bp}$, those of PVY ${ }^{\mathrm{NTN}}$ gave products of 181 and $452 \mathrm{bp}, \mathrm{PVY}^{\mathrm{N}}$ isolates gave a single product of $328 \mathrm{bp}$, and $\mathrm{PVY} \mathrm{Y}^{\mathrm{O}}$ samples gave products of 267 and $689 \mathrm{bp}$. Artificial mixes of isolates gave the expected combinations of products (Fig. 2, Tables 2 and 3).

Overall, there was broad concordance between the multiplex assay and previous characterization of the 119 samples from the University of Idaho and North Dakota State University which were previously characterized using other molecular assays $(3,11,12)$ (Table 3$)$.

The four different PCR assays gave identical results for all isolates that were previously classified as $\mathrm{PVY}^{\mathrm{O}}, \mathrm{PVY}^{\mathrm{N}}, \mathrm{NA}$ $\mathrm{PVY}^{\mathrm{N}}$, and NA-PVY ${ }^{\mathrm{NTN}}$. All $11 \mathrm{PVY}^{\mathrm{O}}$ isolates gave expected products of 267 and 689 bp (Table 3). Thirteen PVY ${ }^{\mathrm{N}}$ isolates produced PCR products of 328 and $398 \mathrm{bp}$. Five isolates produced a single 328-bp product representing NA-PVY ${ }^{\mathrm{N} / \mathrm{NTN}}$. A separate complementary PCR assay was used to verify the NA-PVY ${ }^{\mathrm{N} / \mathrm{NTN}}$ status using an RT-PCR assay (Table 1) that produces an 898-bp product for NA-PVY ${ }^{\text {NTN }}$ but no product for NA-PVYN ${ }^{\mathrm{N}}$ A known

Table 3. Comparison of the new multiplex assay on Potato virus $Y$ (PVY) isolates previously characterized at either the University of Idaho or North Dakota State University (13)

\begin{tabular}{|c|c|c|c|c|c|c|c|c|}
\hline \multirow{2}{*}{$\begin{array}{l}\text { Previous determination } \\
\text { of PVY strain or variant }\end{array}$} & \multirow{2}{*}{$\begin{array}{l}\text { No. of } \\
\text { isolates }\end{array}$} & \multicolumn{6}{|c|}{ New PVY multiplex PCR ${ }^{a}$} & \multirow[b]{2}{*}{ Current analysis } \\
\hline & & 689 bp & 452 bp & 398 bp & 328 bp & 267 bp & $181 \mathrm{bp}$ & \\
\hline $\mathrm{O}$ & $11^{\mathrm{b}}$ & $P$ & $\mathrm{~N}$ & $\mathrm{~N}$ & $\mathrm{~N}$ & $P$ & $\mathrm{~N}$ & $\mathrm{O}$ \\
\hline $\mathrm{N}$ & $13^{\mathrm{b}, \mathrm{c}}$ & $\mathrm{N}$ & $\mathrm{N}$ & $\mathrm{P}$ & $\mathrm{P}$ & $\mathrm{N}$ & $\mathrm{N}$ & $\mathrm{N}$ \\
\hline NA-N/NTN & $\begin{array}{l}4^{\mathrm{b}, \mathrm{c}} \\
1^{\mathrm{b}}\end{array}$ & $\begin{array}{l}\mathrm{N} \\
\mathrm{N}\end{array}$ & $\begin{array}{l}\mathrm{N} \\
\mathrm{N}\end{array}$ & $\begin{array}{l}\mathrm{N} \\
\mathrm{N}\end{array}$ & $\begin{array}{l}\mathrm{P} \\
\mathrm{P}\end{array}$ & $\begin{array}{l}\mathrm{N} \\
\mathrm{N}\end{array}$ & $\begin{array}{l}\mathrm{N} \\
\mathrm{N}\end{array}$ & $\begin{array}{l}\text { NA-N/NTN } \\
\text { NA-NTN }^{d}\end{array}$ \\
\hline NTN & $\begin{array}{l}32^{\mathrm{b}, \mathrm{c}} \\
1^{\mathrm{c}} \\
2^{\mathrm{c}} \\
1^{\mathrm{c}} \\
1^{\mathrm{c}} \\
6^{\mathrm{b}} \\
3^{\mathrm{b}}\end{array}$ & $\begin{array}{l}\mathrm{N} \\
\mathrm{N} \\
\mathrm{N} \\
\mathrm{N} \\
\mathrm{N} \\
\mathrm{P} \\
\mathrm{P}\end{array}$ & $\begin{array}{l}\mathrm{P} \\
\mathrm{N} \\
\mathrm{N} \\
\mathrm{P} \\
\mathrm{P} \\
\mathrm{P} \\
\mathrm{P}\end{array}$ & $\begin{array}{l}\mathrm{N} \\
\mathrm{P} \\
\mathrm{N} \\
\mathrm{P} \\
\mathrm{N} \\
\mathrm{N} \\
\mathrm{N}\end{array}$ & $\begin{array}{l}\mathrm{N} \\
\mathrm{P} \\
\mathrm{P} \\
\mathrm{P} \\
\mathrm{P} \\
\mathrm{N} \\
\mathrm{N}\end{array}$ & $\begin{array}{l}\mathrm{N} \\
\mathrm{N} \\
\mathrm{N} \\
\mathrm{N} \\
\mathrm{N} \\
\mathrm{N} \\
\mathrm{P}\end{array}$ & $\begin{array}{l}\mathrm{P} \\
\mathrm{N} \\
\mathrm{N} \\
\mathrm{P} \\
\mathrm{P} \\
\mathrm{P} \\
\mathrm{P}\end{array}$ & $\begin{array}{l}\text { NTN } \\
\text { N } \\
\text { NA-N/NTN } \\
\text { N + NTN } \\
\text { NA-N/NTN + NTN } \\
\text { NTN + N:O } \\
\mathrm{O}^{e}+\text { NTN }\end{array}$ \\
\hline Necrotic N:O & $7^{\mathrm{b}}$ & $\mathrm{P}$ & $\mathrm{N}$ & $\mathrm{N}$ & $\mathrm{N}$ & $\mathrm{N}$ & $\mathrm{P}$ & $\mathrm{N}: \mathrm{O}$ \\
\hline Non-necrotic N:O & $\begin{array}{r}31^{\mathrm{b}} \\
6^{\mathrm{b}}\end{array}$ & $\begin{array}{l}\mathrm{P} \\
\mathrm{P}\end{array}$ & $\begin{array}{l}\mathrm{N} \\
\mathrm{N}\end{array}$ & $\begin{array}{l}\mathrm{N} \\
\mathrm{N}\end{array}$ & $\begin{array}{l}\mathrm{N} \\
\mathrm{N}\end{array}$ & $\begin{array}{l}\mathrm{N} \\
\mathrm{P}\end{array}$ & $\begin{array}{l}\mathrm{P} \\
\mathrm{P}\end{array}$ & $\begin{array}{l}\mathrm{N}: \mathrm{O} \\
\mathrm{O}+\mathrm{N}: \mathrm{O}\end{array}$ \\
\hline
\end{tabular}

${ }^{\text {a }}$ Polymerase chain reaction. $\mathrm{P}=\mathrm{PCR}$ product produced. $\mathrm{N}=$ no $\mathrm{PCR}$ product produced.

${ }^{\mathrm{b}}$ Isolates from North Dakota State University.

${ }^{\mathrm{c}}$ Isolates from the University of Idaho.

${ }^{\mathrm{d}}$ Refers to NA-PVY ${ }^{\mathrm{NTN}}$ isolate NE-11.

e May also have N:O within the mixture. 
NA-PVY ${ }^{\text {NTN }}$ isolate, Tu 660, produced a single 898-bp product in this subsequent assay. One putative NA-PVY ${ }^{\mathrm{NTN}}$ isolate, NE-11, failed to produce the expected 898bp product.

There were $44 \mathrm{PVY}^{\mathrm{N}: \mathrm{O}}$ isolates, including both tuber necrotic types and types not displaying tuber necrosis. Among these, only 6 isolates gave differing results in this multiplex assay. These 6 isolates produced products of 181,267 , and $689 \mathrm{bp}$, indicating a mixed infection of $\mathrm{PVY}^{\mathrm{O}}$ and $\mathrm{PVY}^{\mathrm{N}: \mathrm{O}}$ (Table 3). This particular type of mixed infection should have been detected using the duplex RT-PCR that separates PVY isolates into the tobacco necrotic $\left(\mathrm{PVY}^{\mathrm{N} / \mathrm{NTN} / \mathrm{N}: \mathrm{O}}\right)$ and nonnecrotic groups $\left(\mathrm{PVY}^{\mathrm{O}}\right)(11)$. These same 6 isolates were retested using the Nie and Singh (11) duplex RT-PCR. Again, only a single 443-bp product was produced by the duplex RTPCR assay for these isolates, falsely indicating single infections of $\mathrm{PVY}^{\mathrm{N}}$ origin.

The greatest discrepancies were among the isolates that were initially classified as PVY ${ }^{\mathrm{NTN}}$. Out of a total of 46 "PVY ${ }^{\mathrm{NTN}}$ " isolates, 32 were confirmed as PVY ${ }^{\mathrm{NTN}}$ by producing PCR products of 181 and 452 $\mathrm{bp}$, corresponding to previous data (Table $3)$. The remaining 14 were reclassified or represented mixed infections. One "PVYNTN" isolate was reclassified as PVY ${ }^{\mathrm{N}}$ because it produced PCR products of 328 and $398 \mathrm{bp}$. Two isolates were reclassified as NA-PVY ${ }^{\mathrm{N} / \mathrm{NTN}}$ because they produced a single product of $328 \mathrm{bp}$. A single isolate produced PCR products of 181, 328, 398, and $452 \mathrm{bp}$, indicating a mixed infection of $\mathrm{PVY}^{\mathrm{NTN}}$ and $\mathrm{PVY}^{\mathrm{N}}$, while another isolate produced PCR products of 181, 328, and $452 \mathrm{bp}$, indicating a mixed infection of PVYNTN and NA-
$\mathrm{PVY}^{\mathrm{N} / \mathrm{NTN}}$. Six isolates produced products of 181, 452, and $689 \mathrm{bp}$, indicating mixed infections of $\mathrm{PVY}^{\mathrm{NTN}}$ and $\mathrm{PVY}^{\mathrm{N}: \mathrm{O}}$. Four isolates produced bands of 181, 267, 452, and $689 \mathrm{bp}$, indicating a mixed infection of $\mathrm{PVY}^{\mathrm{NTN}}$ and PVY ${ }^{\mathrm{O}}$ (or possibly PVY ${ }^{\mathrm{NTN}}$, $\mathrm{PVY}^{\mathrm{O}}$, and $\mathrm{PVY}^{\mathrm{N}: \mathrm{O}}$, which would give an identical pattern).

\section{DISCUSSION}

Since its introduction into North America, the pathotype known as PVY ${ }^{\mathrm{N}: \mathrm{O}}$ has displaced the once predominate strain of $\mathrm{PVY}^{\mathrm{O}}$ in several potato areas due in part to the inability to correctly identify this pathotype (13). It is often observed by both scientists and field personnel that many potato varieties infected with the $\mathrm{PVY}^{\mathrm{N}: \mathrm{O}}$ pathotype have milder symptoms than typically observed when infected with $\mathrm{PVY}^{\mathrm{O}}$ pathotypes. This illustrates the need for accurate laboratory detection to limit their spread. Detection efficiency would be improved through the use of a single assay that can differentiate strains of PVY as opposed to multiple assays.

A common RT-PCR based method to characterize PVY isolates has been a series of two assays that first identifies strain type in the P1 region (11) and then further differentiates the isolates of the $\mathrm{PVY}^{\mathrm{N}}$ type in the $\mathrm{P} 1$ region into nonrecombinant $\left(\mathrm{PVY}^{\mathrm{N}}\right)$ or recombinant strain types with one $\left(\mathrm{PVY}^{\mathrm{N}: \mathrm{O}}, \mathrm{PVY}^{\mathrm{N}}-\mathrm{Wi}\right)$ or three $\left(\mathrm{PVY}^{\mathrm{NTN}}\right)$ recombination junctions (12). The first of these assays should identify strain mixtures of $\mathrm{PVY}^{\mathrm{O}}$ with various $\mathrm{PVY}^{\mathrm{N}}$ types, but will not identify strain mixtures within the set of strains that have a PVY ${ }^{\mathrm{N}}$-type $\mathrm{P} 1$ region. We have experienced that it can be difficult to reliably distinguish NA-PVY ${ }^{\mathrm{N}}$ and NA-PVYNTN from $\mathrm{PVY}^{\mathrm{N}}$ types using this assay, but we have encountered relatively few isolates of the NA-PVY ${ }^{\mathrm{N}}$ and NA-PVY ${ }^{\mathrm{NTN}}$ types (e.g., Table 3). The recombinant junction assay differentiates $\mathrm{PVY}^{\mathrm{N}: \mathrm{O}}$ from $\mathrm{PVY}^{\mathrm{NTN}}$ isolates based on the production of 1 or 3 amplicons, respectively (12). Unfortunately, a mixture of these two strain types will still result in 3 amplicons, with no indication of the underlying infection of $\mathrm{PVY}^{\mathrm{N}: \mathrm{O}}$. A separate published assay can identify mixtures of $\mathrm{PVY}^{\mathrm{N}}$ from $\mathrm{PVY}^{\mathrm{O}}$ (and presumably $\mathrm{PVY}^{\mathrm{N}}$ or $\mathrm{PVY}^{\mathrm{NTN}}$ from $\mathrm{PVY}^{\mathrm{O}}$ or $\mathrm{PVY}^{\mathrm{N}: \mathrm{O}}$ ) based on a specific polymorphic site in the $\mathrm{CP}$ region (18). However, this assay will not identify mixtures of $\mathrm{PVY}^{\mathrm{N}}$ serotypes $\left(\mathrm{PVY}^{\mathrm{N}}+\right.$ $\mathrm{PVY}^{\mathrm{NTN}}$ ) or $\mathrm{PVY}^{\mathrm{O}}$ serotypes $\left(\mathrm{PVY}^{\mathrm{O}}+\right.$ $\left.P V Y^{\mathrm{N}: \mathrm{O}}\right)$. A separate RT-PCR assay of the CP-3'UTR region will identify mixtures of any combinations of $\mathrm{PVY}^{\mathrm{O}}, \mathrm{PVY}^{\mathrm{N}}$, and PVY ${ }^{\mathrm{NTN}}$ (1). Unfortunately, this test must be run as individual assays for each strain type and cannot be performed as a single multiplex reaction. The multiplex assay described in this report will identify any combination of $\mathrm{PVY}^{\mathrm{O}}, \mathrm{PVY}^{\mathrm{N}}, \mathrm{PVY}^{\mathrm{NTN}}$, and $\mathrm{PVY} \mathrm{N}^{\mathrm{N} \mathrm{O}}$, although as tested it will not specifically identify mixtures of $\mathrm{PVY}^{\mathrm{N}}+$ NA-PVY $Y^{\mathrm{N}}$ and/or NA-PVY ${ }^{\mathrm{NTN}}$ or $\mathrm{PVY}^{\mathrm{N}: \mathrm{O}}$ $+\mathrm{PVY}^{\mathrm{N}: \mathrm{O}}$ type B (Fig. 1)

The multiplex identified 17 samples with strain mixtures from 119 previously characterized isolates considered to be single-strain samples (Table 3). This included two isolates with $\mathrm{PVY}^{\mathrm{N}}+\mathrm{PVY}^{\mathrm{NTN}}$, six isolates with $\mathrm{PVY}^{\mathrm{O}}+\mathrm{PVY}^{\mathrm{N}: \mathrm{O}}$, six with $\mathrm{PVY}^{\mathrm{NTN}}+\mathrm{PVY}^{\mathrm{N}: \mathrm{O}}$, and three with $\mathrm{PVY}$ $+\mathrm{PVY}^{\mathrm{NTN}}$ (Table 3). The mixtures of $\mathrm{PVY}^{\mathrm{O}}+\mathrm{PVY}^{\mathrm{N}: \mathrm{O}}$ and $\mathrm{PVY}^{\mathrm{O}}+\mathrm{PVY}^{\mathrm{NTN}}$ should have been detected using the Nie and Singh (11) multiplex assay, which

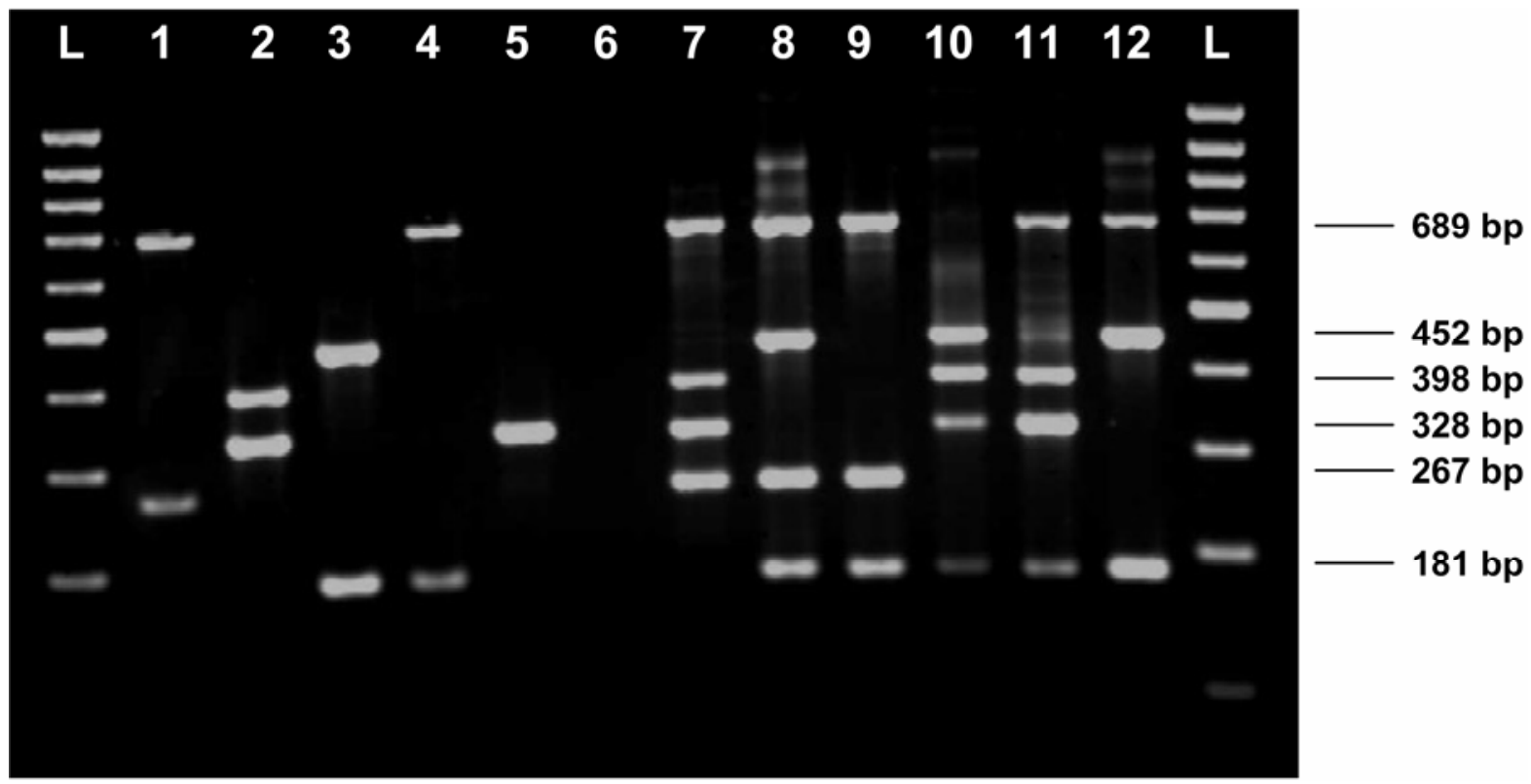

Fig. 2. Separation of polymerase chain reaction (PCR) products produced by the Potato virus $Y$ (PVY) strain types detected by this assay and artificial mixtures of the above strain types. From left to right: $\mathrm{L}=100$-bp molecular size ladder, $1=\mathrm{PVY}^{\mathrm{O}}, 2=\mathrm{PVY}^{\mathrm{N}}, 3=\mathrm{PVY}^{\mathrm{NTN}}, 4=\mathrm{PVY}$ :O $, 5=\mathrm{NA}-\mathrm{PVY} / \mathrm{NTN}, 6=$ negative control, $7=\mathrm{PVY}^{\mathrm{O}}+\mathrm{PVY}^{\mathrm{N}}, 8=\mathrm{PVY}^{\mathrm{O}}+\mathrm{PVY}^{\mathrm{NTN}}, 9=\mathrm{PVY}^{\mathrm{O}}+\mathrm{PVY}^{\mathrm{N}: \mathrm{O}}, 10=\mathrm{PVY}^{\mathrm{N}}+\mathrm{PVY}^{\mathrm{NTN}}, 11=\mathrm{PVY}^{\mathrm{N}}+\mathrm{PVY}^{\mathrm{N}: \mathrm{O}}, 12=\mathrm{PVY}^{\mathrm{NTN}}+\mathrm{PVY}^{\mathrm{N}: \mathrm{O}}, \mathrm{L}^{\mathrm{N}}$ = 100-bp molecular size ladder. 
would be expected to display the PVY ${ }^{\mathrm{O}}$ specific 281-bp band for mixtures that included $\mathrm{PVY}^{\mathrm{O}}$. Perhaps variability in primer affinity or genetic variability at the $\mathrm{PVY}^{\mathrm{O}}$ primer touchdown site gave a competitive advantage to the $\mathrm{PVY}^{\mathrm{N}}$-specific band in the assay (11). The other mixed infections could not have been clearly resolved using previous molecular assays. In fact, the PVY ${ }^{\mathrm{NTN}}+\mathrm{PVY}^{\mathrm{N}: \mathrm{O}}$ mixtures were considered to be a new variant of PVY ${ }^{\text {NTN }}$ because they displayed all biological and molecular aspects of PVY ${ }^{\mathrm{NTN}}$ except that they produced positive serotypes for monoclonal antibodies specific for both PVY ${ }^{\mathrm{O}+\mathrm{C}}(\mathrm{MAb} 2)$ and $\mathrm{PVY}^{\mathrm{N}}(1 \mathrm{~F} 5)$ (13). Although the sample size is not large enough to draw firm conclusions, it is interesting that 11 of the 17 detected strain mixtures contained PVY $\mathrm{Y}^{\mathrm{NTN}}$ as one component. It is possible that PVY ${ }^{\mathrm{NTN}}$ isolates are more compatible in strain mixtures than are other PVY strains and strain variants. This possibility warrants further investigation.

A recently published assay describes the positive detection of $\mathrm{PVY}^{\mathrm{N}}-\mathrm{Wi}$ types in a long-distance PCR, which in combination with another PCR assay for PVY ${ }^{\mathrm{NTN}}$ can identify strain mixtures of PVYNTN plus PVY ${ }^{\mathrm{N}}-\mathrm{Wi}$ (or PVY ${ }^{\mathrm{N}: \mathrm{O}}$ ) (7). However, longdistance PCR is expensive and can be prone to failure. The Glais et al. (7) assay could be used to distinguish two-way mixtures of $\mathrm{PVY}^{\mathrm{O}}+\mathrm{PVY}^{\mathrm{NTN}}$ from three-way mixtures of $\mathrm{PVY}^{\mathrm{O}}+\mathrm{PVY}^{\mathrm{N}: \mathrm{O}}+\mathrm{PVY}^{\mathrm{NTN}}$, which would have identical patterns in this multiplex assay. The multiplex assay described here is robust and inexpensive, and has been successfully transferred to and validated in four additional laboratories besides the originating research group.

Using this multiplex assay, it is possible to detect each of the six possible two-way combinations of the major strains (Fig. 2, Table 3). It is also possible to identify three of the four possible three-way combinations $\left(\mathrm{PVY}^{\mathrm{N}: \mathrm{O}}+\mathrm{PVY}^{\mathrm{NTN}}+\mathrm{PVY}^{\mathrm{O}}\right.$ cannot be resolved from $\mathrm{PVY}^{\mathrm{O}}+$ $\left.\mathrm{PVY}^{\mathrm{NTN}}\right)$. The relatively high percentage of mixed infections detected in this study (>10\%) may represent sampling bias because the collections included some isolates with "unique" field symptoms. However, the presence of even a low rate of natural mixed infections indicates a continued possibility of the emergence of new additional recombinant strains. Potyviruses have been reported to have a relatively high rate of recombination (14). Although origins are uncertain, the similar genetic structure of the $5^{\prime}$ half of the virus, and nearly identical recombination junction near position $2400 \mathrm{bp}$ (6), suggest that the set of PVY ${ }^{\mathrm{NTN}}$ strain isolates may be derived from an original $\mathrm{PVY}^{\mathrm{N}}-\mathrm{Wi}\left(\mathrm{PVY}^{\mathrm{N}: \mathrm{O}}\right)$ recombinant isolate.

The PCR assay described here enables the characterization of major PVY strains and the detection of strain mixtures in a single assay. In addition to the 119 isolates reported here, we have used this or a previous version of the assay on over 1,000 additional PVY-positive samples, most of which have been partially characterized by serological or biological data (unpublished data). In our experience, it has been more robust than the previously mentioned assays, with fewer false positives, false negatives, or ambiguous results. A previous version of the multiplex assay gave several instances of only single bands for $\mathrm{PVY}^{\mathrm{O}}$ isolates. Generally, reamplification produced the expected two bands for these isolates (unpublished data); some laboratory to laboratory variation was noted that was attributed to Taq source or thermocycler variability. Sequence analysis of the relevant region for problematic isolates identified several polymorphisms in the primer sites and led to the current assay that has been much more robust. Should additional primer modifications be required and prove superior, they will be posted on http://marvin.ibest.uidaho.edu/ jlorenze.

Future research will be important to differentiate the various types of $\mathrm{PVY}^{\mathrm{N}: \mathrm{O}}$. Recent studies demonstrate that some types of $\mathrm{PVY}^{\mathrm{N}: \mathrm{O}}$ isolates can cause tuber necrosis while others do not (13). Sequencing to conduct comparisons of the tuber necrotic $\mathrm{PVY}^{\mathrm{N}: \mathrm{O}}$ isolates versus the nontuber necrotic isolates has been initiated (9). One known PVY strain variant that affects potato will not be uniquely identified by this assay. Isolates of the PVY ${ }^{\mathrm{N}}-\mathrm{Wi}$ (or $\mathrm{PVY}^{\mathrm{N}: \mathrm{O}}$ ) variants known as type A and type B (6) will not be differentiated, because the assay does not query the region of the $\mathrm{P} 1$ gene in which the $\mathrm{B}$ variant differs by a portion of $\mathrm{PVY}^{\mathrm{O}}$ sequence in the first 500 bases of the 5'UTR and P1 gene (Fig. 1). We have developed a simple PCR assay to be employed with isolates of the $\mathrm{PVY}^{\mathrm{N}: \mathrm{O}}$ type that uniquely identifies the type B variants (Table 1; unpublished data). The multiplex assay as used with eight primers will not identify mixtures of $\mathrm{PVY}^{\mathrm{N}}$ and $\mathrm{NA}-\mathrm{PVY}^{\mathrm{N}}$ and/or NA-PVY ${ }^{\text {NTN }}$, which share a common 328bp fragment size. A separate assay to confirm presence of NA-PVY ${ }^{\mathrm{N}}$ and NA$\mathrm{PVY}^{\mathrm{NTN}}$ has been developed (Table 1; unpublished data). This latter primer pair is also compatible with the multiplex assay in a 10-primer multiplex that gives two specific bands for each strain variant, including NA-PVY ${ }^{\mathrm{N}}$ and NA-PVY ${ }^{\mathrm{NTN}}$ variants (unpublished data).

Recharacterization of the 119 isolates enabled the identification of one unique isolate with unexpected molecular characteristics. Isolate NE-11 produced a single band of $328 \mathrm{bp}$, indicating it was an isolate of the NA-PVY ${ }^{\mathrm{N} / \mathrm{NTN}}$ strain variant class. However, the confirmatory assay failed to produce a band of 898 bp as would be expected for NA-PVYN ${ }^{\mathrm{N}}$ isolates (Table 1). This isolate has been shown to produce tuber necrosis under greenhouse conditions and has a pathotype of PVY ${ }^{\text {NTN }}$ regarding tuber symptoms (13). These results indicate a unique molecular genotype for NE11, which has been submitted for fullgenome sequencing.

In conclusion, we report on a new multiplex assay that can identify each of the major PVY strains and strain mixtures in a single RT-PCR reaction. This assay was useful in identifying strain mixtures in two archived collections of PVY isolates. It should be useful for other researchers and seed certification agencies that would like to identify PVY strains and strain mixtures.

\section{ACKNOWLEDGMENTS}

We thank Laurent Glais and Camille Kerlan for helpful discussions about detecting mixed infections. Funding for this study was provided by USDA-ARS grants 59-0790-3-066 and 59-0790-2066. We thank P. Hamm, who conducted the initial immunoassay-based screening and provided many of the isolates to the University of Idaho reported in Table 3. We acknowledge the excellent technical assistance of Heidi Hobbs, who conducted many of the original P1 cleaved amplified polymorphic sequence assays.

\section{LITERATURE CITED}

1. Boonham, N., Walsh, K., Preston, S., North, J., Smith, P., and Barker, I. 2002. The detection of tuber necrotic isolates of Potato virus $Y$, and the accurate discrimination of $\mathrm{PVY}, \mathrm{PVY}^{\mathrm{N}}$, or $\mathrm{PVY}^{\mathrm{C}}$ strains using RT-PCR. J. Virol. Methods 102:103-112.

2. Chrzanowska, M. 1991. New isolates of the necrotic strain of potato virus $\mathrm{Y}\left(\mathrm{PVY}^{\mathrm{N}}\right)$ found recently in Poland. Potato Res. 34:179-182.

3. Crosslin, J. M., Hamm, P. B., Shiel, P. J., Hane, D. C., Brown, C. R., and Berger, P. H. 2005. Serological and molecular detection of tobacco veinal necrosis isolates of Potato virus $\mathrm{Y}\left(\mathrm{PVY}^{\mathrm{N}}\right)$ from potatoes grown in the western United States. Am. J. Potato Res. 82:263-269.

4. De Bokx, J. A., and Huttinga, H. 1981. Potato Virus Y. Descriptions of Plant Viruses, No. 242. Commonw. Mycol. Inst./Assoc. Appl. Biol., Kew, England.

5. Draper, M. D., Pasche, J. S., and Gudmestad, N. C. 2002. Factors influencing PVY development and disease expression in three potato cultivars. Am. J. Potato Res. 79:155-165.

6. Glais, L., Tribodet, M., and Kerlan, C. 2002. Genomic variability in potato Potyvirus $Y$ (PVY): Evidence that PVY ${ }^{\mathrm{N}} \mathrm{W}$ and PVY ${ }^{\mathrm{NTN}}$ variants are single to multiple recombinants between $\mathrm{PVY}^{\mathrm{O}}$ and $\mathrm{PVY}^{\mathrm{N}}$ isolates. Arch. Virol. 147:363-378.

7. Glais, L., Tribodet, M., and Kerlan, C. 2005 Specific detection of the $\mathrm{PVY}^{\mathrm{N}}-\mathrm{W}$ variant of Potato virus Y. J. Virol. Methods 125:131-136.

8. Le Romancer, M., Kerlan, C., and Nedellec, M. 1994. Biological characterization of various geographical isolates of Potato virus $Y$ inducing superficial necrosis on potato tubers. Plant Pathol. 43:138-144.

9. Lorenzen, J. H., Meacham, T., Berger, P. H., Shiel, P. J. Crosslin, J. M., Hamm, P. B., and Kopp, H. 2006. Whole genome characterization of Potato Virus Y isolates collected in the western USA and their comparison to isolates from Europe and Canada. Arch. Virol. In press.

10. McDonald, J. G., and Kristjansson, G. T. 1993. Properties of strains of potato virus $\mathrm{Y}^{\mathrm{N}}$ in North America. Plant Dis. 77:87-89.

11. Nie, X., and Singh, R. P. 2002. A new approach for the simultaneous differentiation of 
biological and geographical strains of Potato virus Y by uniplex and multiplex RT-PCR. J. Virol. Methods 104:41-54.

12. Nie, X., and Singh, R. P. 2003. Specific differentiation of recombinant $\mathrm{PVY} \mathrm{N}^{\mathrm{N}: \mathrm{O}}$ and $\mathrm{PVY} \mathrm{Y}^{\mathrm{NTN}}$ isolates by multiplex RT-PCR. J. Virol. Methods 113:69-77.

13. Piche, L. M., Singh, R. P., Nie, X., and Gudmestad, N. C. 2004. Diversity among Potato virus $Y$ isolates obtained from potatoes grown in the
United States. Phytopathology 94:1368-1375.

14. Revers, F., Le Gall, O., Candresse, T., LeRomancer, M., and Dunez, J. 1996. Frequent occurrence of recombinant potyvirus isolates. $\mathrm{J}$. Gen. Virol. 77:1953-1965.

15. Shukla, D. D., Ward, C. W., and Brunt, A. A. 1994. The Potyviridae. Cambridge University Press, Cambridge.

16. Silberschmidt, K. 1960. Types of Potato virus $\mathrm{Y}$ necrotic to tobacco: History and recent ob- servation. Am. Potato J. 37:151-159.

17. Smith, K. M., and Dennis, R. W. G. 1940 Some notes on a suspected variant of Solanum virus 2 (Potato virus Y). Ann. Appl. Biol. 27:65-70.

18. Walsh, K., North, J., Barker, I., and Boonham, N. 2001. Detection of different strains of Potato virus $Y$ and their mixed infections using competitive fluorescent RT-PCR. J. Virol. Methods 91:167-173. 